\title{
Reconstructing salinity changes and environmental influence on dinoflagellate cysts in the central Baltic Sea since the late 19th century
}

\author{
Sildever Sirje ${ }^{1}$, Ribeiro Sofia ${ }^{2,{ }^{*},}$, Mertens Kenneth ${ }^{3}$, Andersen Thorbjørn Joest ${ }^{4}$, Moros Matthias ${ }^{5}$, \\ Kuijpers Antoon ${ }^{2}$
}

\begin{abstract}
${ }^{1}$ Tallinn University of Technology, Department of Marine Systems, Akadeemia tee 15A, 12618, Tallinn, Estonia

${ }^{2}$ Geological Survey of Denmark and Greenland, Department of Glaciology and Climate, Øster Voldgade 10, $1350 \mathrm{~K}$, Copenhagen, Denmark

${ }^{3}$ IFREMER, ODE/UL/LER BO, Station de Biologie Marine de Concarneau, Place de la Croix, 40 29900, Concarneau, France

${ }^{4}$ University of Copenhagen, Department of Geosciences and Natural Resource Management, Øster Voldgade 10, $1350 \mathrm{~K}$, Copenhagen, Denmark

${ }^{5}$ Leibniz Institute for Baltic Sea Research Warnemünde, Department of Marine Geology, Seestraße 15, D-18119, Rostock, Germany
\end{abstract}

*Corresponding author : Sofia Ribeiro, email address : sri@geus.dk

\begin{abstract}
:
We present a record of dinoflagellate cyst assemblage composition, abundance, and morphology from the central Baltic Sea, spanning from the late 19th to the early 21 st century. Environmental time-series were analyzed in relation to changes in community structure and diversity as inferred from the sediment record, and average summer sea surface salinity (SSS) was reconstructed based on the average process length of Protoceratium reticulatum resting cysts. The reconstructed summer SSS was compared to instrumental data for a critical evaluation of this approach. The most abundant species in this record were $P$. reticulatum and Biecheleria baltica, and on average ten taxa were identified per sample. The cyst record of $B$. baltica indicated that although this species has been present in the Gotland Basin at least since the 1880s, its concentrations have increased significantly since the 1980s, possibly linked to eutrophication. Variations in assemblage composition and $P$. reticulatum cyst morphology reflected patterns of major, instrumentally recorded hydrographic and environmental changes in the Baltic Sea during the past century. The variability in microfossil relative abundances was best explained by the average spring SSS as well as by the average $\mathrm{NO}_{3}$ concentrations during spring and by the combined effects of average summer SSS and NAO index variability. Reconstructed summer SSS and instrumental SSS showed notable differences, depending on the year and function applied for reconstruction. Although roughly reflecting the same patterns, the reconstructed values are offset when compared to instrumental measurements. We put forward suggestions for improvement of the process-length method and recommend using the reconstructed values as an indication of relative changes in past summer sea surface salinity, preferably as part of a multiproxy approach.
\end{abstract}




\section{Highlights}

- Dinoflagellate cyst assemblage analysis from 19th century to present. Statistical analysis on the influence of environmental parameters to microfossils. - Average summer sea surface salinity reconstructions based on cyst morphology. Most abundant species were Protoceratium reticulatum and Biecheleria baltica. S Spring SSS, $\mathrm{NO}_{3}$, summer SSS, $\mathrm{NAO}$ best explained variability in microfossil abundances. Cyst assemblages and morphology reflected major environmental changes.

Keywords : Dinoflagellate cysts, environmental change, sea surface salinity, sediment core records, 43 Protoceratium reticulatum, Baltic Sea 


\section{Introduction}

The Baltic Sea, located in northeast Europe, is one of the largest brackish water bodies in the world. It has a rather dynamic geological history, including periods when it was fresh, brackish and also more saline than today (Andrén et al., 2011). Today, Baltic Sea salinity is determined by limited inflows from the North Sea (Lass and Matthäus, 2008; Leppäranta and Myrberg, 2009) and large freshwater input from rivers, especially to the northern and eastern basins (Bergström and Carlsson, 1994; Johansson, 2017). This generates a surface salinity gradient from around 3 in the Bay of Bothnia to around 8 in the Arkona basin (Leppäranta and Myrberg, 2009). As salinity is negatively correlated with the energy required for osmotic regulation, (Schlieper, 1971), lower salinity levels result in an overall reduced biodiversity (Elmgren and Hill, 1997; Ojaveer et al., 2010). Model simulations indicate that the surface salinity in the Baltic Sea is likely to decrease in the future (Meier et al., 2012) due to the projected increase in winter precipitation across the entire region and also increased summer precipitation in the north (von Storch et al., 2015). However, due to uncertainties in the climate models, the projected changes in the surface salinity are not clear (von Storch et al., 2015) and thus, reliable reconstruction methods are needed to provide further insight to past environmental changes.

Dinoflagellates are unicellular eukaryotes forming an ecologically important group of microplankton in various aquatic environments (Dale and Dale, 2002). Around 200 marine dinoflagellate species are known to produce resting cysts (Ellegaard et al., 2017 and references therein), as part of their life cycle, mainly triggered by changes in the environment (Anderson and Lindquist, 1985; Ellegaard et al., 1998; Figueroa et al., 2005; Kremp et al., 2009). Thus, assemblage composition, abundance, and morphology can reflect the conditions prevailing at the time of cyst formation (Ellegaard et al., 2002; Godhe and McQuoid, 2003; Price and Pospelova, 2011; Heikkilä et al., 2016). The coupling between modern dinoflagellate cyst assemblages and corresponding environmental conditions (Godhe and McQuoid, 2003; Price et al., 2017) can be used to infer past environmental conditions. For example, dinoflagellate cyst records have been used to investigate past changes in sea surface conditions, such as temperature (e.g., Brinkhuis et al., 1998, de Vernal, et al. 2001, Bringué et al., 2018), salinity (e.g., Wall \& Dale, 1973; Head et al., 2004; Sorrel et al., 2006), sea-ice cover (e.g., Durantou et al., 2012), as well as changes in regional climate variability vs. anthropogenic change (e.g., Ribeiro et al., 2016) and in water quality due to eutrophication (e.g. Dale \& Fjellså, 1994; Dale, et al. 1999; Price, et al. 2018). Variations in cyst morphology of Lingulodinium polyedra (Verleye, et al. 2009; Mertens, et al. 2012a) and Protoceratium reticulatum (Mertens, et al. 2011; Ning et al. 2017) have been used to respectively quantitatively reconstruct salinity changes in the Black Sea and along the Baltic Sea-Skagerrak salinity gradient.

In recent decades, dinoflagellates have become more dominant in some basins of the Baltic Sea, especially during spring (Wasmund and Uhlig, 2003; Klais et al., 2011). This change influences the benthic communities through food quality and quantity as well as through oxygen consumption at the water-sediment interface (Klais et al., 2011; Spilling, et al. 2018). The dinoflagellates Peridiniella catenata (Levander) Balech, Biecheleria baltica Moestrup, Lindberg \& Daugbjerg, Apocalathinium malmogiense (G. Sjöstedt) Craveiro, Daugbjerg, Moestrup \& Calado and Gymnodinium corollarium Sundström, Kremp \& Daugbjerg are key members of the spring bloom in the northern Baltic Sea (Heiskanen and Kononen, 1994; Hällfors et al., 2013; Klais et al., 2013; Lips et al., 2014). While P. catenata has been recorded in the Baltic Sea since 1903 (Hällfors et al., 2013), data on the vegetative stage of B. baltica is lacking due to the inability to distinguish it from A. malmogiense and G. corollarium with light microscopy. However, B. baltica and $P$. catenata have been well documented from surface sediments of the northern Baltic Sea (Kremp, 2000a, b; Olli and Trunov, 2010; Sildever et al., 2017) and the expansion of B. baltica cyst beds have been 
suggested to promote the blooms dominated by this species in the Gulf of Finland (Klais et al., 2011). The increase in B. baltica cyst abundances during has been shown to coincide with the increase in anthropogenic eutrophication from 1930s to 1960s , (Kremp et al., 2018), which exemplifies the influence of human activities to the phytoplankton communities and sea ecosystem. The Holocene history of the Baltic Sea has been previously investigated based on sedimentary records (Kotilainen et al., 2014; Warden et al., 2016; Kotthoff et al., 2017), including information from the Gotland basin (Brenner, 2001a; b; 2005; Kabel et al., 2012). More specifically, past surface salinity changes in the Baltic Sea have been quantitatively studied by using different proxies such as dinoflagellate cyst morphology (Willumsen et al., 2013) and strontium isotopic composition $\left({ }^{87} \mathrm{Sr} /{ }^{86} \mathrm{Sr}\right)$ of mollusk shells (Widerlund and Andersson, 2011; Ning et al., 2017). Comparison between reconstructed surface salinities based on the average process length of cysts $P$. reticulatum and strontium isotopic composition indicated consistently higher salinities reconstructed by using average process lengths (Ning, et al. 2017). Thus, the average process-length based reconstructions were suggested to overestimate the salinity and are therefore not as reliable as other methods, e.g. strontium isotopic composition (Ning, et al. 2017). However, mollusk shells are not present in sediments younger than 2775 years BP (Widerlund and Anderson, 2011) and thus other proxies are needed to cover this period. Salinity reconstructions based on average process length of cysts of $P$. reticulatum have not been attempted for the most recent period, as the previous studies cover 8800 - 2800 yrs BP (Willumsen, et al. 2013) and appr. 7300 - 3500 yrs BP (Ning, et al. 2017). Furthermore, the temporal resolution in those studies is around hundred to a few hundred years, which does not allow for resolving decadal to the centennial timescales that may be influenced by e.g. North Atlantic Oscillation (NAO) patterns (Weckström, et al. 2017). Also, to increase the confidence of dinoflagellate cyst-based proxies, it is important to compare dinoflagellate cyst based reconstructions with time-series of instrumental measurements (Harland et al., 2006).

In this study, the reliability of the process-length method for salinity reconstructions is evaluated by comparing the reconstructed values from the late $19^{\text {th }}$ century to the early $21^{\text {st }}$ century with available instrumental data. Furthermore, changes in dinoflagellate cyst assemblage composition and morphology from the Gotland Basin during the same period are presented and analyzed in relation to environmental parameters to detect potential changes due to factors influencing the marine environment over decadal timescales, such as freshwater input and NAO variability.

\section{Materials and Methods}

\subsection{Sediment core sampling and dating}

The sediment core used in this study was retrieved in 2009 from the Gotland basin (Figure 1; $57^{\circ} 23.00 \mathrm{~N} 20^{\circ} 15.50 \mathrm{E}$, water depth $231 \mathrm{~m}$, core ID 570530-5) with a multi-corer in the framework of the EU BONUS project INFLOW. The core was halved lengthwise for imaging and sampled at $0.5-1 \mathrm{~cm}$ intervals. The samples were subsequently freeze-dried for further analyses. Three laminated intervals were observed in the core: $22-27.5 \mathrm{~cm}(0-5.5 \mathrm{~cm}, 2009-1999), 29.51-40.3$ $\mathrm{cm}(7.5-18.28 \mathrm{~cm}, 1995-1966)$ and $41.51-54 \mathrm{~cm}(19.39-31.89,1962-1932)$. The crosssection of the core is shown in Suppl. Figure 1. The samples analyzed in this study do not cover the core with the same frequency, e.g. there is a break between 1955 and 1975 as well as between 1922 and 1932. The sediment samples were analyzed for ${ }^{210} \mathrm{~Pb},{ }^{226} \mathrm{Ra}$, and ${ }^{137} \mathrm{Cs}$ activity via gamma spectrometry at the Gamma Dating Centre, Department of Geography and Geology, University of Copenhagen. The measurements were carried out on a Canberra low background Germanium welldetector. ${ }^{210} \mathrm{~Pb}$ was measured by way of its gamma-peak at $46.5 \mathrm{keV},{ }^{226} \mathrm{Ra}$ by way of the granddaughter ${ }^{214} \mathrm{~Pb}$ (peaks at 295 and $352 \mathrm{keV}$ ) and ${ }^{137} \mathrm{Cs}$ by way of its peak at $661 \mathrm{keV}$. The chronology of the core was established using a slightly modified constant rate of supply (CRS) 
model (Appelby, 2001) as presented in Kabel et al. (2012). The ${ }^{210} \mathrm{~Pb}$ and ${ }^{137} \mathrm{Cs}$ data are shown in

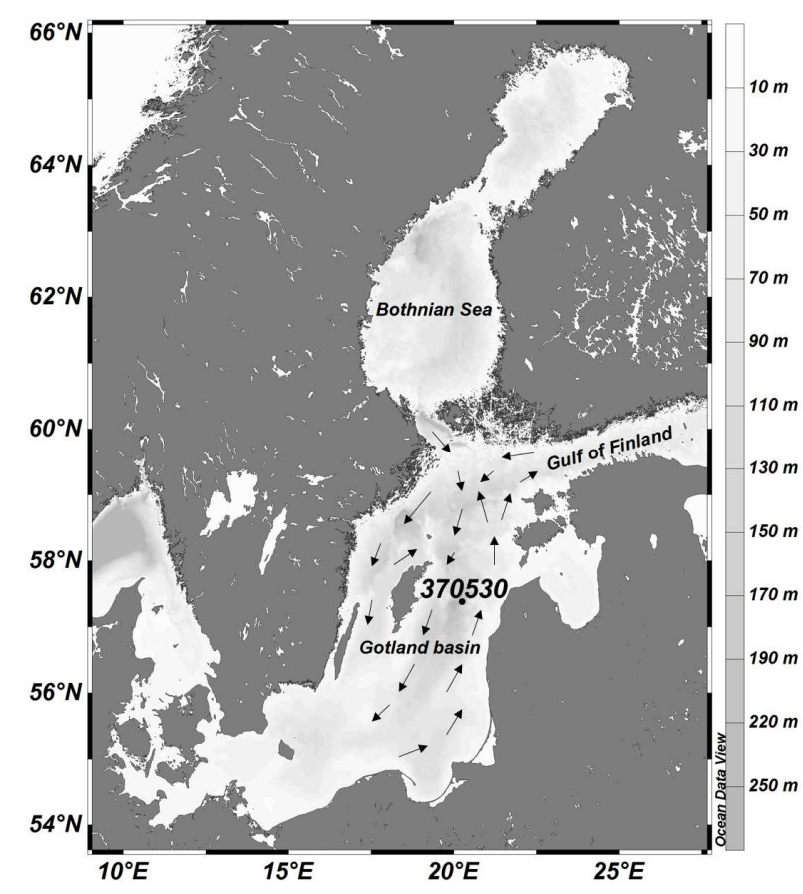

Figure 1. Core site in the Gotland basin, Baltic Sea. Arrows indicate general surface circulation patterns (based on Leppäranta \& Myrberg, 2009)

\subsection{Dinoflagellate cyst analysis}

Sediment core samples were processed at the Research Unit Palaeontology, Ghent University, using a standard methodology including cold $\mathrm{HCl}$ and $\mathrm{HF}$ treatment, and sieving through $10 \mu \mathrm{m}$ meshes (Fig. 1 in Mertens et al., 2009), with Lycopodium clavatum as an exotic marker. Dinoflagellate cysts were identified and counted on permanent microscope slides and to ensure statistical significance, 300 cysts were counted per sample, whenever possible (Mertens et al., 2009). For the samples yielding $<300$ cysts, all the prepared material (several slides) was counted. Fragments representing less than half a cyst were not considered. The freshwater algae Pediastrum spp. were also counted in parallel and considered an additional indicator of freshwater input. Absolute abundances are given as cysts per gram of dry sediment calculated from the equation: (number of counted cysts*number of spores of L. clavatum added to the sample) / (number of L. clavatum spores counted*sample weight) (modified after Stockmarr, 1971).

Cysts of Protoceratium reticulatum were grouped into three different morphotypes, differentiated by their process development and length, i.e. morphotypes with a) fully developed processes, $>5$ $\mu \mathrm{m}, \mathrm{b})$ reduced processes, $<5 \mu \mathrm{m}$, based on the process lengths applied by Ellegaard (2000) and c) bald cysts with no processes. Colorless cysts of gonyaulacoid affinity with no processes were grouped as unidentified mucus cysts (UMC). Species belonging to the genus Spiniferites were merged as Spiniferites spp., which includes Spiniferites sp., S. elongatus, S. belerius, S. bulloideus, and $S$. bentorii. Heterotrophic cysts not identifiable to species level were counted as round brown (RB) cysts. Species belonging to the genus Dubridinium were merged as Dubridinium spp. 
consisting of Dubridinium sp., D. caperatum and D. ulsterum. Raw count data is available as Suppl. Table 1.

\subsection{Calibration and quantitative reconstruction}

The process lengths of $P$. reticulatum cysts were measured with an inverted Olympus IX 51 microscope, Olympus cellSens Dimension imaging software, and Olympus U-CMAD3 Digital Camera. To ensure uniformity of the measurements, the three longest visible processes were measured in 20 cysts of $P$. reticulatum per sample/age-depth. Processes were measured from the center of the process base to the tip of the process (Mertens et al., 2011). Bald cysts of $P$. reticulatum were not included in the reconstruction following Mertens, et al. 2011. Samples for which less than 20 cysts of $P$. reticulatum were measured (2008, 2004 and 1994), were excluded from the reconstruction as well. The average process length of cysts of $P$. reticulatum was available from 90 surface sediment samples from previous studies in the Baltic Sea region (Suppl. Table 2). The correlation between average process length and average summer sea surface salinity (SSS) (July-September) was analyzed using the gridded 1-degree World Ocean Atlas 2005 (Antonov et $a l ., 2006)$ and the Ocean Data View software (Schlitzer, 2017) by calculating Pearson's correlation coefficients (r). The significance of Pearson's $r$ was then calculated using a t-test. Different functions based on the previous measurements were applied to the average process lengths from the core to reconstruct average SSS from the end of the $19^{\text {th }}$ to the beginning of $21^{\text {st }}$ century. The equation proposed by Mertens et al. (2011), where SSS $=3.16^{*}$ average process length -0.84 $\left(\mathrm{R}^{2}=0.80\right)$, was also applied in order to compare existing models.

\subsection{Environmental data}

To investigate the influence of environmental parameters on the dinoflagellate community structure and diversity as well as to compare the reconstructed sea surface salinity with actual measurements, different time-series were used. Instrumental time-series for salinity, temperature, nutrients, and Chl $a$ from the sampling area were obtained from the Oceanography database of ICES (2017). The measurements originate from the Gotland basin area, which is defined by the following coordinates in the database: $\mathrm{S}-\mathrm{W}: 56^{\circ} \mathrm{N} 18^{\circ} \mathrm{E}, \mathrm{N}-\mathrm{E} 58^{\circ} \mathrm{N} 21^{\circ} \mathrm{E}$. All available measurements (min. 3 measurements per variable) from the sea surface to $5 \mathrm{~m}$ depth were used for the years from which the sediment samples originate. The depth from 0-5 $\mathrm{m}$ was chosen to characterize the conditions of the layer with the highest phytoplankton biomass, which was estimated based on the available Chl $a$ data. Average SSS and SST were calculated for winter (December-February, data available from 1975 and onwards), spring (March-May, from 1922) and summer (June-August, from 1932). To compare reconstructed SSS with instrumental data, salinity data from July to September was used (from 1922) as this monthly range represents the SSS values used for calibration (Antonov et al., 2006). Average phosphate and nitrate concentrations were calculated for winter (data available starting from 1983), spring and summer (1975) using the same months as for the salinity and temperature. The annual mean freshwater input to the Baltic Proper, including the Gotland basin, was obtained from HELCOM Baltic Sea Environment Fact Sheet (data available until 1955) (Kronsell and Andersson, 2013). Monthly North Atlantic Oscillation (NAO) index (National Weather Service, 2017) was used to calculate average NAO indices for different seasons for each year from which the sediment samples originate (starting from 1955). Reconstructed SST and total organic carbon (TOC) data (Kabel et al., 2012) were used to provide further context to this study.

\section{$\underline{2.5 \text { Statistical analysis }}$}


Ordination analyses were applied to uncover the relationship between the microfossil assemblages (dinoflagellate cysts and Pediastrum spp.) and several environmental parameters using the $\mathrm{R}$ package vegan ( $\mathrm{R}$ Core Team 2018, Oksanen et al., 2018). First, a Detrended Correspondence Analysis (DCA) was performed to choose between linear and unimodal ordination methods. DCA and further analyses were based on microfossil relative abundance data and included only species or groups that had an average relative abundance $>1 \%$. The length of the first DCA axis was always < 2 standard deviations (SD) (Table 1), indicating homogeneous datasets for which linear methods are suitable (Lepš and Šmilauer, 2003). We applied a square-root transformation to the assemblage data to account for very high values (Borcard et al., 2011). Principal Component Analysis (PCA) was performed to investigate general trends in the microfossil data and Redundancy Analysis (RDA) was used to analyze the influence of environmental parameters on the assemblages. Average SSS, SST, NAO index, phosphate and nitrate for different seasons as well as annual average SSS, NAO index and freshwater input were included. As the environmental data was continuously available only until 1983 for winter and until 1975 for other seasons, reduced microfossil datasets were used to match with the environmental datasets (Table 1). Based on the interpretation of the PCA, RDA was performed on microfossil datasets containing only spring (B. baltica, $P$. catenata, RB, Dubridinium sp.) or summer (different morphotypes of P. reticulatum, G. baltica, Spiniferites spp., Pediastrum spp.) species/groups. Monte Carlo Permutation tests with 999 unrestricted permutations were used to test the significance of the variation in microfossil community composition explained by the environmental variables under a global model and if the result was significant, further Monte Carlo permutation tests with 999 unrestricted permutations were performed to test for the variation explained by the individual axes and environmental variables.

\section{Results}

The multiple laminations visible in the core clearly indicate an undisturbed sediment record, and anoxic conditions during the period from 1966 to ca. 2009 (excl. sample from 1997) (Suppl. Fig. 1). Older samples $(1880-1922)$ from the bottom of the core indicate higher oxygen concentrations at the seabed, evidenced by the homogeneous sediment layer dated to ca. 1880-1932.

\subsection{Dinoflagellate cyst assemblages}

Overall, cyst concentrations were generally higher (61 462 cysts $\mathrm{g}^{-1} \mathrm{dw}$, standard deviation, S. D.,

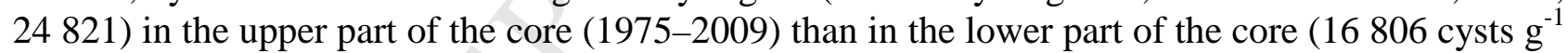
dw, S.D. 6352, 1880-1955) (Figure 2). The number of dinoflagellate taxa identified varied from eight to 16 with an average of ten per sample (Suppl. Table 1). Four taxa were present throughout the core: cysts of $P$. reticulatum, $B$. baltica, round brown cysts and Dubridinium spp. In addition, freshwater algae of the Pediastrum genus were also found throughout the core. The most abundant species were Biecheleria baltica and $P$. reticulatum, the latter represented by three cyst morphotypes (Figure 2). Biecheleria baltica dominated the community in the three topmost samples (2004, 2008 and 2009) and represented 48\% of the assemblage in $2008 \pm 1$ (Figure 3). From 2003 and back, bald cysts of $P$. reticulatum became dominant, constituting 85\% of the assemblages from $1975 \pm 1$. Autotrophic species dominated the cyst assemblage throughout the entire core, with heterotrophs being always below $27 \%$ (Figure 3). 


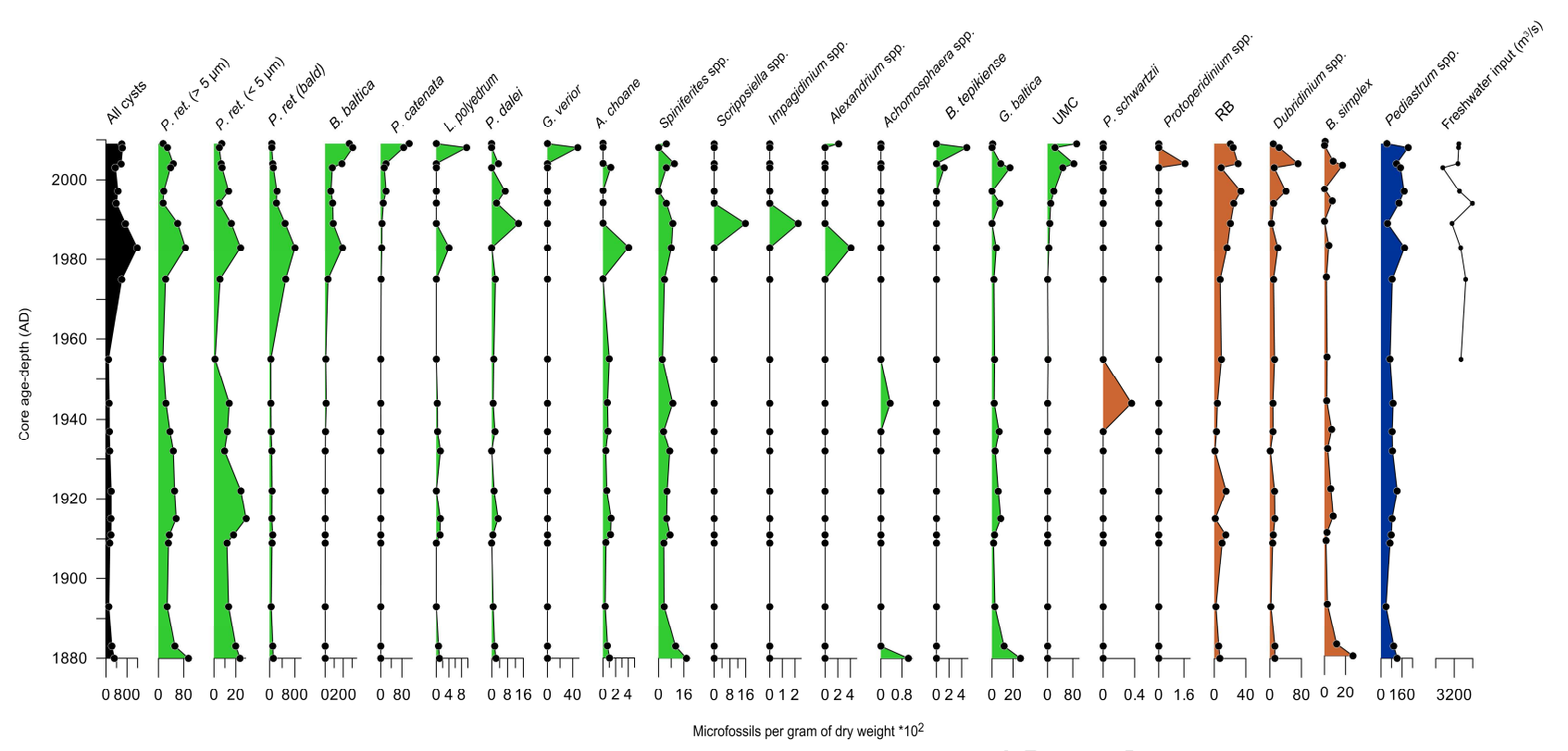

Figure 2. Absolute palynomorph abundance (per gram of dry weight* $10^{2}$ ) plotted together with

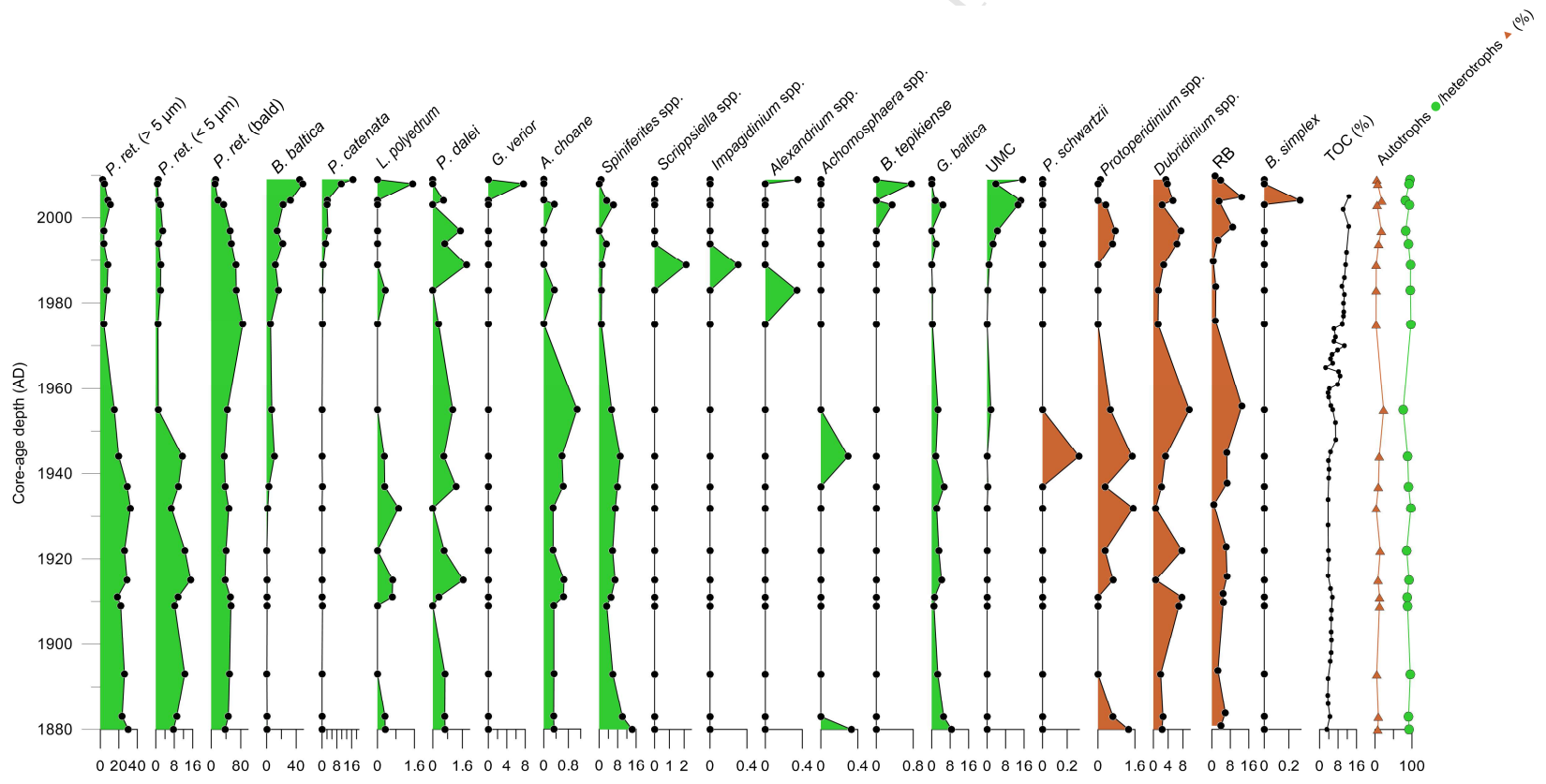

Figure 3. Relative abundances of dinoflagellate cysts (\%), total organic carbon (\%) redrawn from

(Kabel et al., 2012), relative abundances of autotrophs (filled circles) and heterotrophs (filled triangles)

\subsection{Environmental time-series from the Gotland basin}

The available instrumental data on sea surface salinity showed remarkably little variation (Figure

4) both seasonally and annually, as the maximum difference between the minimum and maximum values throughout all seasons and years available was 0.81 . In contrast, the average instrumental 
SST showed a large variability within and between seasons, e.g. winter SST ranged from 2.30 to $5.21{ }^{\circ} \mathrm{C}$, spring SST 1.29 to $6.86{ }^{\circ} \mathrm{C}$, summer SST for June-August 10.91 to $19.29{ }^{\circ} \mathrm{C}$ and JulySeptember 15.87 to $18.89{ }^{\circ} \mathrm{C}$. Reconstructed SST (July-October) by Kabel et al. (2012) ranged from 14.33 to $18.77^{\circ} \mathrm{C}$. The average annual freshwater input to the Baltic Proper ranged from 2706 $\mathrm{m}^{3} / \mathrm{s}$ and $3991 \mathrm{~m}^{3} / \mathrm{s}$. The most positive average NAO index values occurred in 1989 . For the summer season, the most positive average values occurred in 1983 (June-August) and in 1955 (July-September). The most negative average values were recorded in 1955 for the winter season and annually. For spring, the most negative average value was recorded in 1975 and for the summer season (both monthly ranges) in 2008. The TOC concentrations ranged from 2.59 to $12.73 \%$ (Kabel et al., 2012) (Figure 3). The average winter phosphate values ranged from 0.36 to 0.68 $\mu \mathrm{mol} / \mathrm{L}$, for spring the range was from 0.28 to $0.57 \mu \mathrm{mol} / \mathrm{L}$ and for summer 0.06 to $0.17 \mu \mathrm{mol} / \mathrm{L}$ for June-August and 0.02 to 0.09 for July-September. The average nitrate values for winter ranged from 2.6 to $3.66 \mu \mathrm{mol} / \mathrm{L}$, for spring 1.43 to $8.06 \mu \mathrm{mol} / \mathrm{L}$ and for summer 0.08 to $1.19 \mu \mathrm{mol} / \mathrm{L}$ for June-August and 0.12 to $1.82 \mu \mathrm{mol} / \mathrm{L}$ for July-September.

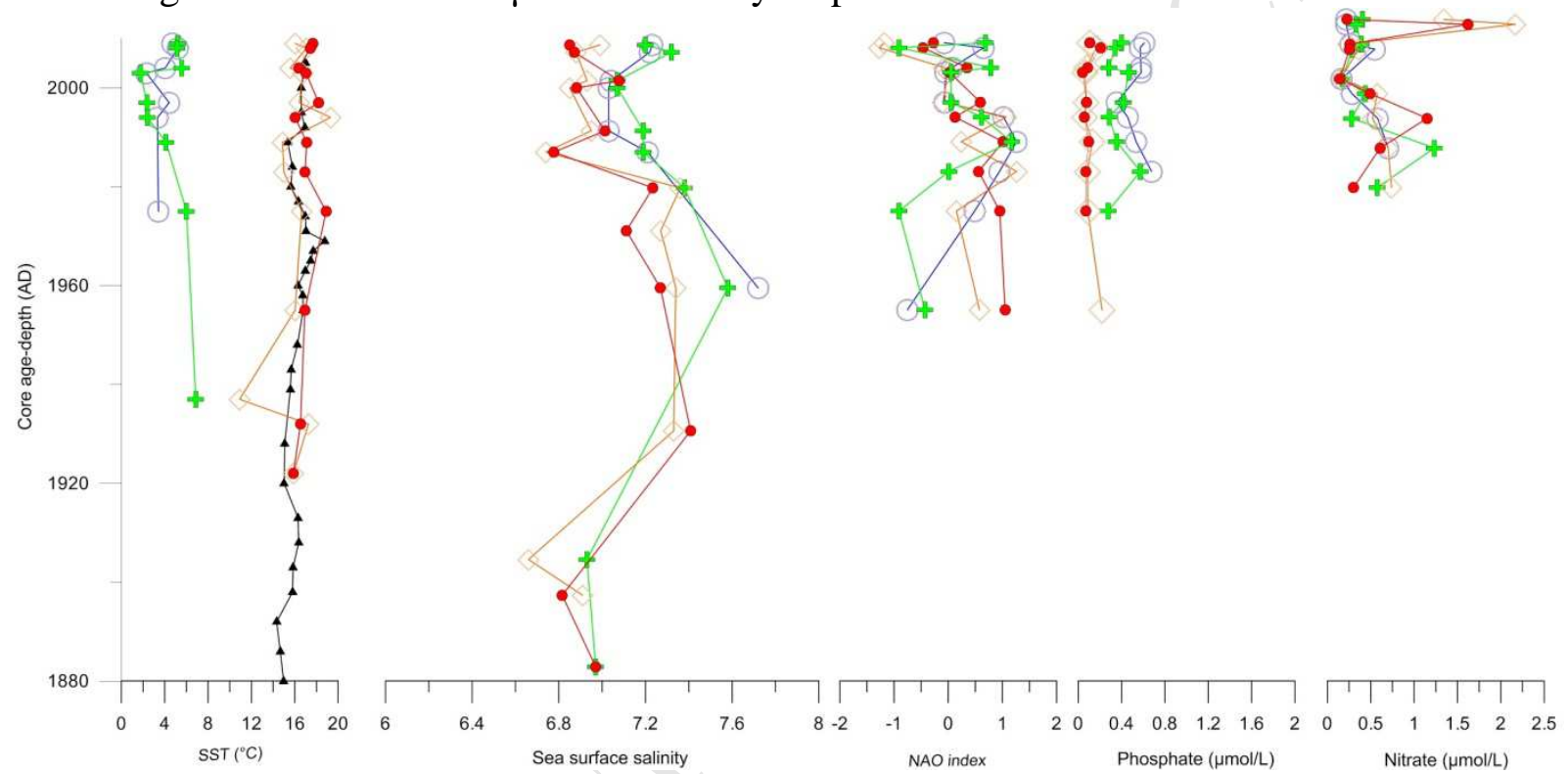

Figure 4. Instrumental data from the Gotland basin during different seasons (empty circles: winter (December-February), filled crosses: spring (March-May), empty diamonds: summer (JuneAugust), filled circles: summer (July-September) and reconstructed sea surface temperature $\left({ }^{\circ} \mathrm{C}\right)$ redrawn from (Kabel et al., 2012) (filled triangles)

\section{$\underline{3.3 \text { Process length measurements, and summer surface salinity reconstructions }}$}

Altogether, $1188 P$. reticulatum processes were measured from a total of 396 cysts. In the upper part of the core (1955-2009), the average process length was between 1.54 and $2.90 \mu \mathrm{m}$, whereas before 1944 it was consistently $\geq 3 \mu \mathrm{m}$. In general, all reconstructions showed a similar pattern in SSS following this shift in average process length (Figure 5). The linear function as presented in Mertens et al. (2011) yielded higher surface SSS values compared to the linear $\left(\mathrm{y}=4.526^{*}\right.$ average process length $\left.-8.58, \mathrm{R}^{2}=0.87\right)$ and exponential $\left(\mathrm{y}=2.172 \mathrm{e}^{0.318^{*} \text { average process length }}, \mathrm{R}^{2}=0.89\right)$ functions derived from our updated calibration dataset (Figure 6, Suppl. Table 2). Compared to the linear function by Mertens et al. (2011), our new linear function produced on average 3 units lower SSS and yielded negative SSS values for two years. When using the new exponential function, the average difference between the SSS values reconstructed with the linear function by (Mertens et al., 2011) was 2 units. The average instrumental SSS for summer (July-September) ranged from 6.82 to 
7.41. At the same time, the average reconstructed SSS was more variable by ranging from 4.02 to 11.22 when using the linear function by (Mertens et al., 2011). When using the new linear function, the average SSS ranged from -1.62 to 8.70 (in Figure 5, the negative values are replaced with zero, as salinity cannot be negative) and with the new exponential function the range was 3.54 to 7.31(Suppl. Table 2).

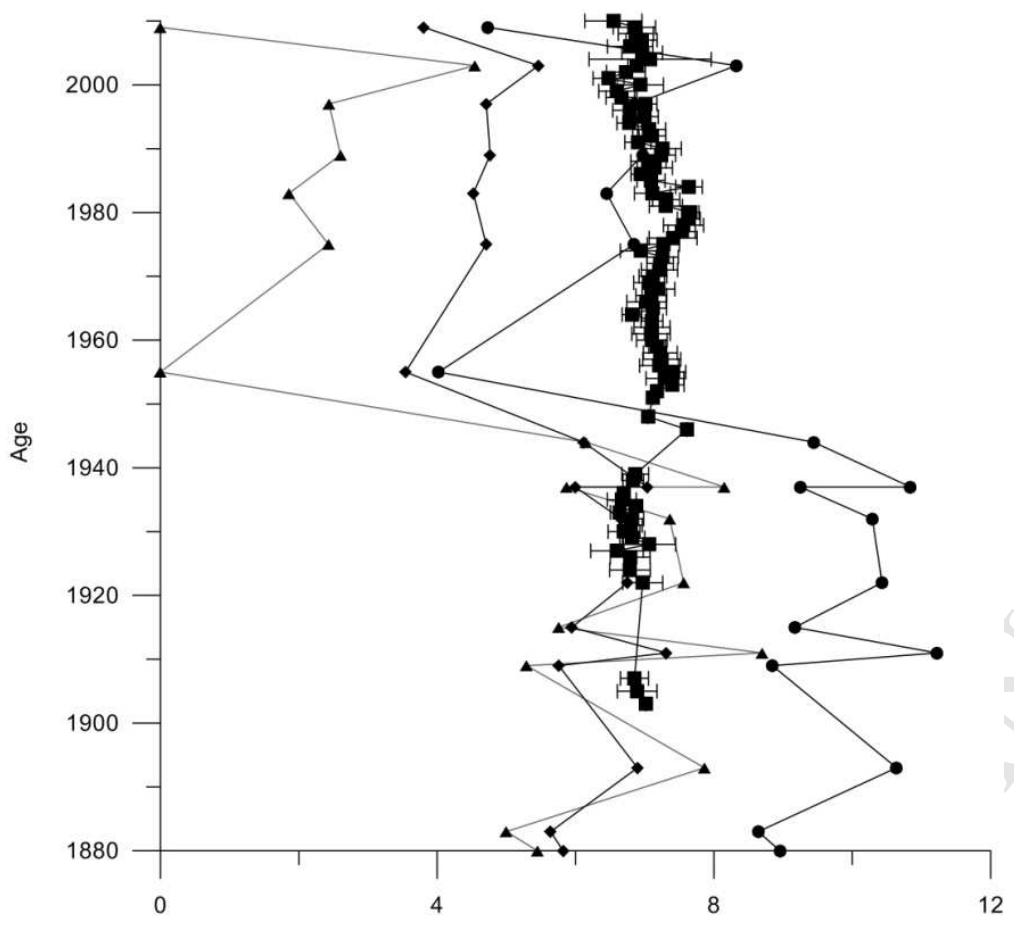

Figure 5. Reconstructed average summer sea surface salinity (triangles: new linear function, diamonds: new exponential function, filled circles: linear function from (Mertens et al., 2011) and squares: average instrumental sea surface salinity for July-September) 

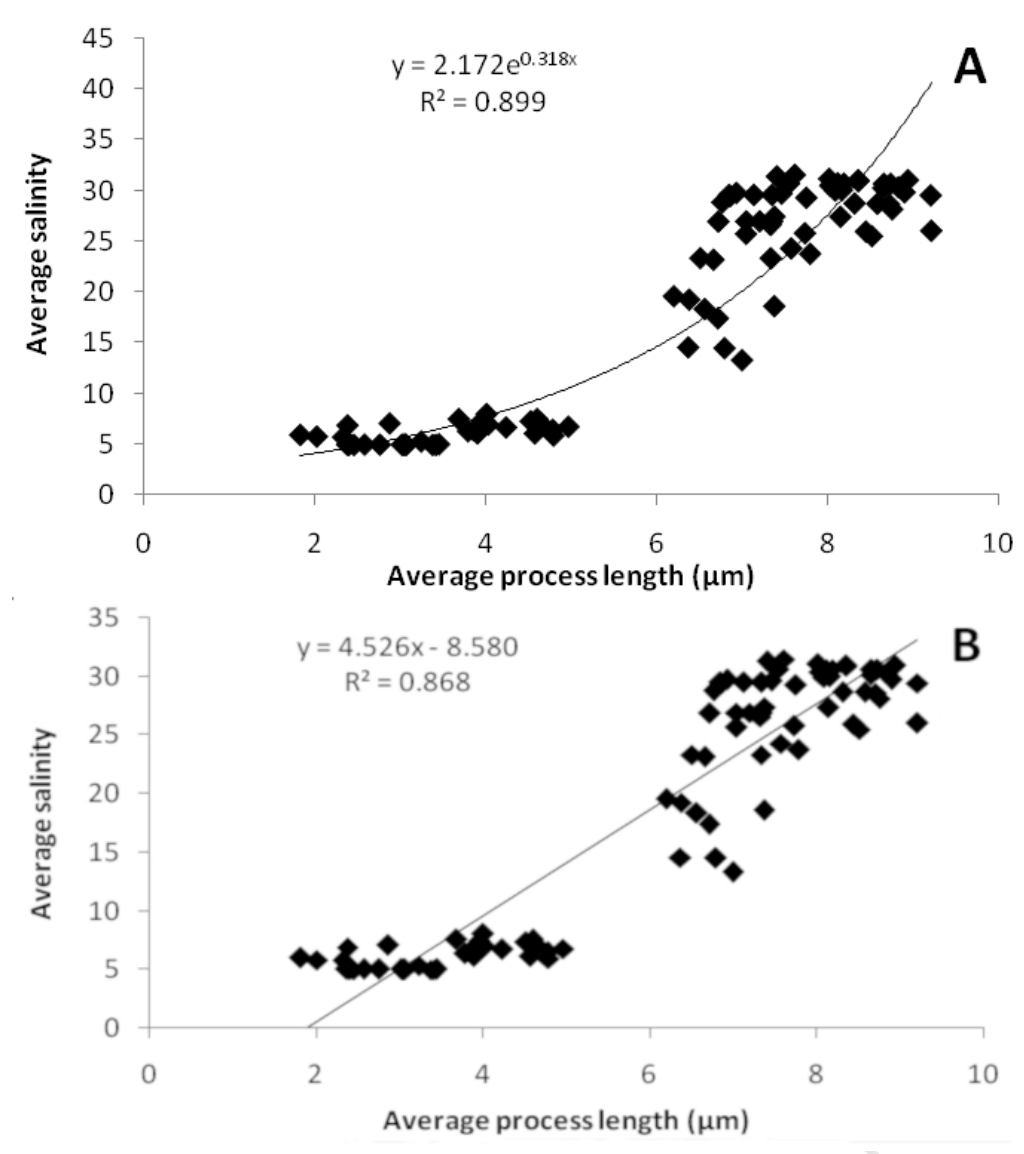

Figure 6. Exponential (A) and linear (B) functions based on the average process length and average surface salinity (July-September, 0-5m depth)

\section{$\underline{\text { 3.4 Statistical analysis }}$}

The first three Principal Component Analyses (PCA) axes explained $79.82 \%$ of the variation in the cyst assemblage data (Figure 7). The first axis had positive associations with $P$. reticulatum (> 5 $\mu \mathrm{m}$ and 0-5 $\mu \mathrm{m})$, G. baltica, Spiniferites spp. and Pediastrum spp. (Suppl. Table 3). The second axis had a strong positive association only with $P$. reticulatum (bald) and showed a negative association with the other taxa. Biecheleria baltica and $P$. catenata contributed positively to the variability represented by the third axis. Most taxa grouped together close to the positive side of the first PCA axis (Figure 7, A, B). Protoceratium reticulatum (bald) grouped separately along the second axis, whereas $B$. baltica and $P$. catenata grouped together on the negative side along the first PCA axis. Dubridinium spp., RB and Pediastrum spp. also grouped separately from other species/groups along the first PCA axis. When first and third axes are shown (Figure 7, C, D), $B$. baltica and $P$. catenata grouped together on the positive side of the third PCA axis, whereas $P$. reticulatum (bald) was placed on the negative side of both axes. Dubridinium spp., RB and Pediastrum spp. still grouped separately from other species/groups along the first PCA axis, whereas other species/groups were clustered together on the positive side of the first PCA axis. In the RDA with annual and seasonal environmental data, the variability explained by different axes was relatively low, e.g. the first four axes explained $<50 \%$ of the variability in the microfossil data in relation with environmental parameters. For annual data, the three first axes explained $18.7 \%$ of 
the variability. Global Monte Carlo permutation tests returned statistically non-significant ( $\mathrm{p}>$ 0.05) for the majority of the seasons and for the annual dataset (Table 1). The global test was significant for spring environmental parameters and all microfossil taxa $(p=0.043)$ (Table 1). The permutation test for individual axes indicated the importance of the first axis $(\mathrm{P}=0.045)$ and SSS was identified as a parameter significantly $(\mathrm{p}=0.033)$ influencing the microfossil community composition. The global Monte Carlo test was significant between environmental parameters from spring and spring species $(\mathrm{p}=0.022)$, with the variation represented by the first axis statistically significant $(\mathrm{p}=0.015)$ and with $\mathrm{NO}_{3}$ and SSS significantly $(\mathrm{p}<0.05)$ contributing to the variation in species composition (Table 1). For the summer species (i.e. species with the highest abundances in the plankton community during summer months), environmental parameters from spring and summer (June-August) were significant $(\mathrm{p}<0.04)$, with the first axis statistically significant $(\mathrm{p}<$ 0.05 ) with SSS and NAO values explaining a significant amount of variation in the summer species dataset $(\mathrm{p}<0.04$, Table 1).
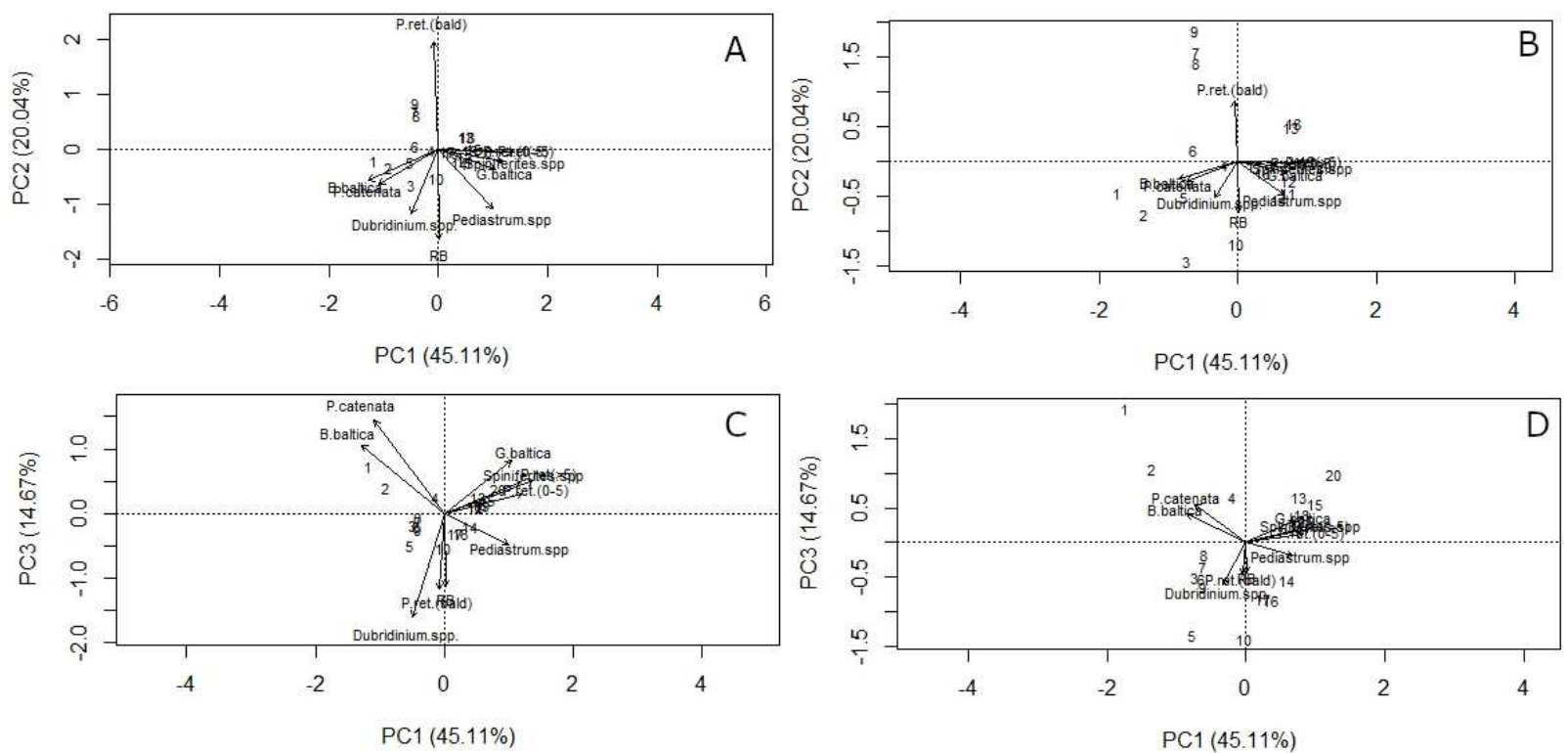

Figure 7. Principal Component Analysis: $\mathbf{A}$ and $\mathbf{C}$ scaling for species, $\mathbf{B}$ and $\mathbf{D}$ scaling for sites

\section{Discussion}

This study provides a detailed overview of dinoflagellate cyst assemblage composition and abundance in the central Baltic Sea, from the end of the $19^{\text {th }}$ century to the early 21 st century. Dinoflagellate cyst diversity (average $=10$ taxa) in the Gotland basin was higher than the diversity reported from surface sediments: $n=3$ (Gundersen, 1988) (note: "Tectatodinium psilatum" from the Baltic is now considered a bald cyst morphotype of $P$. reticulatum) and $n=6$ (Sildever et al., 2015), as well as from another sediment core from the Gotland basin $(n=6$, note: in our study freshwater dinoflagellate species are not included, and "Pyxidiniopsis psilata" from the Baltic is now considered a bald cyst morphotype of $P$. reticulatum) spanning from 11300 to 380 years BP (Brenner, 2005). These differences in species diversity might reflect patchiness in the phytoplankton community or differences in environmental conditions between the years that support the growth of different species. The cyst assemblages were dominated by autotrophic species, i.e. cysts of $P$. reticulatum and cysts of $B$. baltica, whereas the heterotrophic species constituted $<27 \%$ of the community during the investigated period. The change in dinoflagellate cyst total abundances and TOC concentration in the second half of the $20^{\text {th }}$ century might reflect the 
nutrient increase after 1950s, with a peak in 1980s (Gustafsson, et al. 2012). It might also indicate better preservation of cysts due to less frequent inflows of oxygen-rich water to the Baltic Sea after the 1980s (Matthäus, et al. 2006). However, the variation in microfossil relative abundances was not well explained by the different environmental parameters, with an exception of SSS and nitrate concentration during spring and a combination of SSS and NAO during summer. The reconstructed SSS values captured the decrease in surface salinity recorded by instrumental measurements since the 1950s (Fonselius \& Valderrama, 2003), although the reconstructed average SSS values were more variable throughout the core compared to the instrumental average SSS. The difference between the instrumental and reconstructed values also depended on the function used for reconstruction.

\subsection{Patterns in cyst assemblage composition}

Half of the taxa analyzed were positively related with the first PCA axis. Cysts of $P$. reticulatum (> $5 \mu \mathrm{m}$ ) and Spiniferites spp. have been linked to higher surface salinities (e.g. Mertens et al., 2011; Willumsen et al., 2013; Ning et al., 2017), whereas the increased abundance of freshwater algae Pediastrum spp. has been interpreted as an indicator of freshwater transport to the Gotland basin (Brenner, 2005). Thus, the positive contribution of Pediastrum spp. to the first axis suggests a link with increased freshwater input. The main supply of freshwater to the central Baltic Sea comes from the Bothnian Sea and the Gulf of Finland, which reaches to the central Baltic after late summer (Hordoir and Meier, 2010). Protoceratium reticulatum, and Spiniferites spp. occur mainly in summer-autumn (Harland et al., 2004; Hällfors, 2013) when the nutrient supply from the bottom layers to the upper water column is blocked by stratification. Input of freshwater brings in extra nutrients, thus supporting the growth of late summer-autumn dinoflagellates. However, as the spring bloomers $B$. baltica and $P$. catenata are negatively related to the first PCA axis, this likely reflects the seasonal succession, as Pediastrum spp., P. reticulatum, G. baltica, and Spiniferites spp. co-occur in late summer in the central Baltic, whereas the spring bloom dinoflagellates, $B$. baltica, and $P$. catenata, and heterotrophic dinoflagellates of Dubridinum spp. co-occur during spring.

The second axis is mainly driven by bald cysts of $P$. reticulatum, potentially indicating a salinity gradient. The third axis had a positive input from autotrophic dinoflagellate species/groups, with the exception of bald $P$. reticulatum, and negative contribution from heterotrophic species and Pediastrum spp. This axis might represent a stratification gradient as autotrophic dinoflagellates can generally thrive in well-stratified waters (Margalef et al., 1979), whereas higher relative abundances of heterotrophic dinoflagellate species cysts have been found from well-mixed sampling locations as mixing favors diatom availability in the upper layer of the water column (Godhe and McQuoid, 2003).

The main environmental parameter significantly influencing variation in species relative abundances was SSS during spring, which can be interpreted in terms of stratification, favoring dinoflagellates over diatoms and supporting dinoflagellate dominance during the spring bloom (Wasmund and Uhlig, 2003; Klais et al., 2011). In addition to SSS, variation in spring dinoflagellate species relative abundances was also significantly influenced by the nitrate concentrations, a limiting nutrient in eutrophicated areas of the Baltic Sea during the spring bloom (Tamminen and Andersen, 2007). Interestingly, the spring SSS also significantly influenced the variation in summer dinoflagellate communities, which might be explained by the overall strength of water column stratification. For example, increased water column stability induced by the positive phase of winter NAO has been used as a potential explanation to increased abundances of cysts produced by $S$. bentorii during late summer-autumn in Gullmar fjord, west coast of Sweden (Harland et al., 2006). The summer communities were additionally influenced by a combination of summer SSS and NAO values. The positive phase of summer NAO has been correlated with the 
dry, warm and cloud-free conditions in Scandinavia (Folland, et al. 2009), which would potentially increase the summer SSS due to reduced precipitation and promote thermal stratification. Thus, the statistically significant contribution of summer SSS and NAO values to the variability in the summer dinoflagellate assemblages may reflect differences between years with positive and negative summer NAO phases.

\subsection{Species temporal distribution}

Similarly to this study, cysts of $P$. reticulatum (all morphotypes grouped) have been previously recorded as an important, if not dominant, member of the cyst community in the Gotland Basin (Gundersen, 1988; Brenner, 2005; Sildever et al., 2015). In the investigated sediment core, bald cysts of $P$. reticulatum were the dominant morphotype throughout most of the core record. In previous sediment core studies from the Baltic Sea, covering longer time periods, bald cysts of $P$. reticulatum (then identified as Pyxidiniopsis psilata) were found in low abundances and not consistently throughout the records (Brenner, 2001b, 2005; Yu and Berglund, 2007; Ning et al., 2017). Thus, it is suggested that their exceptionally high abundances may indicate specific environmental conditions (Brenner, 2001a). This morphotype of $P$. reticulatum varied opposite to Spiniferites spp., potentially indicating the influence of surface salinity, as Spiniferites spp. abundances have been positively correlated with SSS (Sildever et al., 2015) and displayed a similar pattern with the reconstructed sea surface salinity (Ning et al., 2017). However, bald P. reticulatum cysts peaked in 1975 , representing $85 \%$ of the assemblage, although there was no notable change in freshwater input or instrumental SSS data compared to the previous and following years. Unfortunately, the next cyst data point originates from 1955, not allowing to follow the changes in the relative abundances of the bald cysts of $P$. reticulatum prior to 1975 in more detail.

In the samples originating from 2004-2009, B. baltica was dominant. The earliest presence of $B$. baltica cysts was recorded from 1910 and P. catenata from 1973 in the Baltic Sea by Kremp et al. (2018), whereas in this study the presence of those species can be extended to 1880 and 1909 respectively. Similarly, in both studies, the cysts of $B$. baltica were recorded throughout the core, whereas the cysts of $P$. catenata were not continuously present and the abundances declined rapidly downcore. The cyst wall of $P$. catenata is thin (Kremp, 2000b), which potentially influences the preservation capacity of the cysts (Kremp et al., 2018). The highest absolute cyst abundances were recorded for both species in both studies from the 2000s, although the cyst abundances were higher in the Gulf of Finland (Kremp et al., 2018). This might result from the generally higher spring bloom peak biomass values in the Gulf of Finland compared to the Gotland basin (Klais et al., 2011). In the Gulf of Finland, a marked increase in B. baltica cyst abundances between the 1930s and 1960s was linked to increased nutrient input (Kremp et al., 2018). In the Gotland basin, a rapid increase in B. baltica cyst abundances was found at the beginning of the 1980 s and for $P$. catenata at the end of the 1990s. This might also be explained by the increased nutrient input as the average spring phosphate concentrations were highest in the $1980 \mathrm{~s}\left(0.59 \mu \mathrm{M} \mathrm{L}^{-1}\right)$, whereas the average spring nitrate concentrations had high values from the beginning of 1980 s to the end of 1990s (2.7 $4.08 \mu \mathrm{M} \mathrm{L}^{-1}$ ) (ICES, 2017).

Interestingly, no cysts of A. malmogiense (previously known as Scrippsiella hangoei) were recorded in this study, although they were found throughout the sediment core from the Gulf of Finland (Kremp et al., 2018). In this study, cysts identified as Scrippsiella spp. were found from only one layer corresponding to the year 1989, which is not comparable to the continuous presence in the Gulf of Finland (Kremp et al., 2018). The species was also not recorded in surface sediments from the same site (Sildever et al., 2015) or from the nearby sampling station in the same basin (Sildever et al., 2017). The influence of palynological treatment on the preservation of cysts of $A$. malmogiense is not known (Kremp et al., 2018). Although this treatment was not used by Sildever 
et al. (2017), the potential influence of palynological treatment on the preservation of $A$. malmogiense cysts in our record needs further investigation, even though A. malmogiense is found in low numbers in the phytoplankton (Sundström et al., 2009).

The abundances of heterotrophic taxa grouped under Dubridinium spp. and RB varied throughout the core with higher total abundances in the upper part of the core (from 1975) following the increased TOC concentrations, potentially indicating increased productivity (e.g. Andrén et al., 2000). High abundances of cysts produced by heterotrophic dinoflagellates were also found from the surface sediment samples from the same core and from a neighboring sampling location in the northern Baltic Proper, and in those samples, heterotrophic cysts also dominated the assemblage (Sildever et al., 2015). The dominance of heterotrophic cysts in the surface sediments has been related to the conditions favoring the growth of their prey (Godhe and McQuoid, 2003) and thus elevated nutrient levels favoring the growth of the prey organisms have been suggested as a potential explanation (Sildever et al., 2015). This is further supported by the results of RDA, where the spring nitrate concentrations significantly contributed to the variability in the relative abundances of both autotrophic spring dinoflagellate species and heterotrophic species. Interestingly, in the older sediments of the Gotland basin core, the cysts of heterotrophic dinoflagellates always constituted $<27 \%$ of the assemblage. Another explanation might be related with the better preservation of the cysts as most of the samples between 1975 to 2009 originate from low oxygen, possibly anoxic conditions, whereas from 1880 to 1955 the majority of the samples originates from higher oxic conditions (e.g. Zonneveld, et al. 2007).

\subsection{Summer sea surface salinity reconstruction}

Comparing reconstructed average summer SSS (July-September) values with the average instrumental data allows for en evaluation of the $P$. reticulatum process-length method as a summer SSS proxy. Compared to instrumental SSS values, which ranged only up to 0.59 , the SSS reconstructions showed wider ranges. Higher reconstructed sea surface salinity values based on the average process length of cysts of $P$. reticulatum compared to previous studies (Willumsen et al., 2013), as well as with other proxies and microfossil abundances have been reported (Ning et al., 2017) and thus the process length based reconstruction might overestimate salinity (Ning et al., 2017). The usage of a linear function to describe the relationship between average process length and environmental parameters has been criticized by Jansson et al. (2014) due to the indistinguishable influence of different parameters on the average process length, which hinders the usage of average process length as a proxy for a specific environmental parameter, e.g. SSS or SST. At the same time, salinity has been found to be a more important factor contributing to the variability in the average process length in comparison to temperature and nutrient concentrations (Jansson et al., 2014)

Another limitation to this approach is that the available average modern process lengths do not represent the entire salinity gradient as measurements are lacking from intermediate surface salinities around 5-6 (Suppl. material 1, Mertens et al., 2011). Thus, adding more process length data from those salinities is likely to increase the accuracy of the models used for reconstructing the summer SSS. However, before adding new data it might be necessary to investigate the $P$. reticulatum populations from different localities in the Baltic Sea by using molecular methods as the presence of genetically differentiated populations of $P$. reticulatum has been suggested (Jansson et al., 2014) based on the differences in the $P$. reticulatum ITS sequences from the Baltic Sea, Canada and Japan (Mertens et al., 2012b). Using the model calibrated with process length data from genetically differentiated populations would not accurately represent the relationship between the average process length and environmental parameters alone (Jansson et al., 2014), which might 
explain the differences between the reconstructed and instrumental/calculated values. Until further development of this approach, the reconstructed values are more reliable as qualitative rather than quantitative indicators.

\section{Conclusions}

With the aim to reconstruct salinity changes in the Baltic Sea since the late 19th century, we investigated a dated sedimentary record from Gotland Basin. Changes in the cyst assemblage composition down-core were compared to historical hydrographic time-series from the area, and the process length of Protoceratium reticulatum cysts was used to numerically reconstruct summer seasurface salinity (SSS) using different numerical models. The main conclusions of this study are:

1) Dinoflagellate cyst total abundance and reconstructed SSS values generally followed the instrumentally-recorded changes in nutrient concentrations, SSS and bottom water inflow episodes.

2) Assemblage composition was mainly influenced by the spring SSS, but spring-blooming taxa were additionally influenced by $\mathrm{NO}_{3}$ concentrations, and summer-occurring species showed variability induced by the combination of average summer SSS and NAO values.

3) Reconstructed average summer surface salinities differed and were more variable compared to the average instrumental summer surface salinities. Thus, it is recommended to use the process length based reconstructed values as a qualitative indicator pending further developments of this approach.

\section{Acknowledgments}

The sediment core material used in this study was collected within the INFLOW (The Holocene Saline Water Inflow Changes into the Baltic Sea) project, funded by the European Commission 7th Framework Programme (FP/2007e2013) under Grant agreement No. 217246. Writing of the manuscript was supported by the institutional research funding (IUT 19-6) of the Estonian Ministry of Education and Research. This study is a contribution to project SEDI-TRAPS funded by GEOCENTER Denmark.

\section{Tables}

Table 1. Datasets used for ordination analyses and the results of Monte Carlo permutation tests

\section{Figures}

Figure 1. Sampling location in the Gotland basin, the Baltic Sea. Arrows indicate the long-term mean surface circulation (redrawn from Leppäranta \& Myrberg, 2009)

Figure 2. Absolute palynomorph abundance (per gram of dry weight* $10^{2}$ ) plotted together with average annual freshwater input $\left(\mathrm{m}^{3} \mathrm{~s}^{-1}\right)$

Figure 3. Relative abundances of dinoflagellate cysts (\%), total organic carbon (\%) redrawn from (Kabel et al., 2012), relative abundances of autotrophs (filled circles) and heterotrophs (filled triangles) 
Figure 4. Instrumental data from the Gotland basin during different seasons (empty circles: winter (December-February), filled crosses: spring (March-May), empty diamonds: summer (JuneAugust), filled circles: summer (July-September) and reconstructed sea surface temperature $\left({ }^{\circ} \mathrm{C}\right)$ redrawn from (Kabel et al., 2012) (filled triangles)

Figure 5. Reconstructed average summer sea surface salinity (triangles: new linear function, diamonds: new exponential function, filled circles: linear function from (Mertens et al., 2011) and squares: average instrumental sea surface salinity for July-September)

Figure 6. Exponential (A) and linear (B) functions based on the average process length and average surface salinity (July-September, 0-5m depth)

Figure 7. Principal Component Analysis: A and $\mathbf{C}$ scaling for species, $\mathbf{B}$ and $\mathbf{D}$ scaling for sites

\section{Supplementary material}

Suppl. Figure 1. Cross-section of the core 570530-5

Suppl. Figure 2. Radiometric data from the core $570530-5, \mathbf{A}:{ }^{210} \mathrm{~Pb}\left(\mathrm{~Bq} \mathrm{~kg}^{-1}\right)$, the $\mathrm{X}$-axis is $\log (10)$ transformed, $\mathbf{B}:{ }^{137} \mathrm{Cs}\left(\mathrm{Bq} \mathrm{kg}^{-1}\right)$, error bars indicate standard deviation

Suppl. Figure 3. Core age-depth model

Suppl. Table 1. Dinoflagellate cyst counts

Suppl. Table 2. Calibration and reconstruction data

Suppl. Table 3. Species loadings for PCA axes

\section{References}

Anderson, D. M., Lindquist, N. L. (1985) Time-course measurements of phosphorus depletion and cyst formation in the dinoflagellate Gonyaulax tamarensis Lebour. J. Exp. Mar. Bio. Ecol. 86, $1-13$.

Andrén, E., Andrén, T., Kunzendorf, H. (2000) Holocene history of the Baltic Sea as a background for assessing records of human impact in the sediments of the Gotland Basin. Holocene 10, $687-702$.

Andrén, T., Björck, S., Andrén, E., Conley, D., Zillén, L., Anjar, J. (2011) The Development of the Baltic Sea Basin During the Last 130 ka. In, Harff, J., Björck, S., and Hoth, P. (eds), The Baltic Sea Basin. Central and Eastern European Development Studies (CEEDES). Springer, Berlin, Heidelberg, pp. 75-97.

Antonov, J. I., Locarnini, R. A., Boyer, A. V., Mishonov, A. V., Garcia, H. E. (2006) World Ocean Atlas 2005, Volume 2: Salinity Levitus, S. (ed) U.S. Government Printing Office, Washington D.C.

Appelby, P. (2001) Chronostratigraphic Techniques in Recent Sediments. In, Last, W. and Smol,J. (eds), Tracking Environmental Change Using Lake Sediments. Volume 1: Basin analysis, Coring and Chronological Techniques. Kluwer, Dordrecht, pp. 171-203. 
606

607

608

609

610

611

612

613

614

615

616

617

618

619

620

621

622

623

624

625

626

627

628

629

630

631

632

633

634

635

636

637

638

639

640

641

642

643

644

645

646

647

648

649

650

651

652

653

Bergström, S., Carlsson, B. (1994) River runoff to the Baltic Sea: 1950-1990. Ambio 23, 280-287. Borcard, D., Gillet, F., Legendre, P. (2011) Numerical Ecology with R Gentleman, R., Parmigiani,G. G., and Hornik, K. (eds) Springer, New York.

Brenner, W. W. (2001a) Distribution of organic walled microfossils within single lamina from the Gotland Basin, and their environmental evidence. Baltica 14, 34-39.

Brenner, W. W. (2005) Holocene environmental history of the Gotland Basin (Baltic Sea) - A micropalaeontological model. Palaeogeogr. Palaeoclimatol. Palaeoecol. 220, 227-241.

Brenner, W. W. (2001b) Organic-walled microfossils from the central Baltic Sea, indicators of environmental change and base for ecostratigraphic correlation. Baltica 14, 40-51.

Brinkhuis, H., Bujak, J. P., Smit, J., Versteegh, G. J. M., Visscher, H. (1998) Dinoflagellate-based sea surface temperature reconstructions across the Cretaceous-Tertiary boundary. Palaeogeogr. Palaeoclimatol. Palaeoecol. 141, 67-83.

Dale, B. 1996. Dinoflagellate cyst ecology: modelling and geological applications. In: Jansonius, J. \& McGregor, D. C. (eds.): Palynology: Principles and Applications 3, 1249-1275. AASP Foundation, Dallas, TX.

Dale, B., Dale, A. (2002) Environmental applications of dinoflagellate cysts and acritarchs. In, Haslett, S. (ed), Quaternary Environmental Micropaleontology. Arnold, London, pp. 207-240.

Dale B., Fjellså A. (1994) Dinoflagellate Cysts as Paleoproductivity Indicators: State of the Art, Potential, and Limits. In: Zahn R., Pedersen T.F., Kaminski M.A., Labeyrie L. (eds) Carbon Cycling in the Glacial Ocean: Constraints on the Ocean's Role in Global Change. NATO ASI Series (Series I: Global Environmental Change), vol 17. Springer, Berlin, Heidelberg

Dale, B., Thorsen, T.A., Fjellså, A. (1999). Dinoflagellate cysts as indicators of cultural eutrophication in the Oslofjord, Norway. Estuar. Coast. Shelf Sci. 48, 371-382.

de Vernal, A., Henry, M., Matthiessen, J., Mudie, P. J., Rochon, A., Boessenkool, K. P., Eynaud, E., Grøsfjeld, K., Guiot, J., Hamel, D., Harland, R., Head, M. J., Kunz-Pirrung, M., Levac, E., Loucheur, V., Peyron, O., Pospelova, V., Radi, T., Turon, J.-L., Voronina, E. (2001) Dinoflagellate cyst assemblages as tracers of sea-surface conditions in the northern North Atlantic , Arctic and sub-Arctic seas : the new ' $\mathrm{n}=677^{\text {' }}$ data base and its application for quantitative palaeoceanographic reconstruction. J. Quat. Sci. Sci. 16, 681-698.

Durantou, L., Rochon, A., Ledu, D., Massé, G., Schmidt, S., Babin, M. (2012) Quantitative reconstruction of sea-surface conditions over the last $150 \mathrm{yr}$ in the Beaufort Sea based on dinoflagellate cyst assemblages: The role of large-scale atmospheric circulation patterns. Biogeosciences 9, 5391-5406.

Ellegaard, M. 2000. Variations in dinoflagellate cyst morphology under conditions of changing salinity during the last 2000 years in the Limfjord, Denmark. Rev. Palaeobot. Palynol. 109, 65-81.

Ellegaard, M., Dale, B., Mertens, K. N., Pospelova, V., Ribeiro, S. (2017) Dinoflagellate Cysts as Proxies for Holocene Environmental Change in Estuaries: Diversity, Abundance and Morphology. In: Weckström, K., Saunders, K. M., Gell, P. A., Skilbeck, C. G. (eds), Applications of Paleoenvironmental Techniques in Estuarine Studies. Developments in Paleoenvironmental Research, vol 20. Springer Netherlands, Dordrecht, pp. 295-312.

Ellegaard, M., Kulis, D. M., Anderson, D. M. (1998) Cysts of Danish Gymnodinium nolleri Ellegaard et Moestrup sp. ined. (Dinophyceae): studies on encystment, excystment and toxicity. J. Plankton Res. 20, 1743-1755.

Ellegaard, M., Lewis, J., Harding, I. (2002) Cyst-theca relationship, life cycle, and effects of temperature and salinity on the cyst morphology of Gonyaulax baltica sp. nov. (Dinophyceae) from the Baltic Sea area. J. Phycol. 789, 775-789.

Elmgren, R., Hill, C. (1997) Ecosystem function at low biodiversity - the Baltic example. In, 
654

655

656

657

658

659

660

661

662

663

664

665

666

667

668

669

670

671

672

673

674

675

676

677

678

679

680

681

682

683

684

685

686

687

688

689

690

691

692

693

694

695

696

697

698

699

700

701

Ormond, R. F. G., Gage, J. D., Angel, M. U. (eds), Marine Biodiversity. Patterns and Processes. Cambridge University Press, Cambridge, pp. 319-336.

Figueroa, R. I., Bravo, I., Garcés, E. (2005) Effects of nutritional factors and different parental crosses on the encystment and excystment of Alexandrium catenella (Dinophyceae) in culture. Phycologia 44, 658-670.

Folland, C.K., Knight, J., Linderholm, H.W., Fereday, D., Ineson, S., Hurrell, J.W. (2009). The Summer North Atlantic Oscillation: Past, Present, and Future. J. Climate, 22, 10821103Fonselius, S., Valderrama, J. (2003) One hundred years of hydrographic measurements in the Baltic Sea. J. Sea Res. 49, 229-241.

Godhe, A. McQuoid, M. R. (2003) Influence of benthic and pelagic environmental factors on the distribution of dinoflagellate cysts in the surface sediments along the Swedish west coast. Aquat. Microb. Ecol. 32, 185-201.

Gundersen, N. (1988) En palynologisk unders $\varnothing$ kelse av dinoflagellatcyster langs en synkende salinitetsgradient i recente sedimenter fra Østersjø-området. University of Oslo. MSc thesis. (In Norwegian, with English abstract)

Gustafsson, B.G., Schenk, F., Zorita, E. (2012) Reconstructing the Development of Baltic Sea Eutrophication 1850-2006. Ambio 41 (6), 534-548.

Hällfors, H. (2013) Studies on dinoflagellates in the northern Baltic Sea. University of Helsinki. $\mathrm{PhD}$ thesis. https://helda.helsinki.fi/handle/10138/38315 (04.11.18)

Hällfors, H., Backer, H., Leppänen, J.-M., Hällfors, S., Hällfors, G., and Kuosa, H. (2013) The northern Baltic Sea phytoplankton communities in 1903-1911 and 1993-2005: a comparison of historical and modern species data. Hydrobiologia 707, 109-133.

Harland, R., Nordberg, K., and Filipsson, H. L. (2006) Dinoflagellate cysts and hydrographical change in Gullmar Fjord, west coast of Sweden. Sci. Total Environ. 355, 204-231.

Harland, R., Nordberg, K., and Filipsson, H. L. (2004) The seasonal occurrence of dinoflagellate cysts in surface sediments from Koljö Fjord, west coast of Sweden - a note. Rev. Palaeobot. Palynol. 128, 107-117.

Head, M.J., Seidenkrantz, M.S., Janczyk-Kopikowa, Z., Marks, L., and Gibbard, P.L. (2004) Last Interglacial (Eemian) hydrographic conditions in the southeastern Baltic Sea, NE Europe, based on dinoflagellate cysts. Quat. Int. 130, 3-30.

Heikkilä, M., Pospelova, V., Forest, A., Stern, G.A., Fortier, L., Macdonald, R. W. (2016) Dinoflagellate cyst production over an annual cycle in seasonally ice-covered Hudson Bay. Mar. Micropaleontol. 125, 1-24.

Heiskanen, A.-S., Kononen, K. (1994) Sedimentation of vernal and late summer phytoplankton communities in the coastal Baltic Sea. Arch. fur Hydrobiol. 131, 175-198.

Hordoir, R. and Meier, H. E. M. (2010) Freshwater fluxes in the Baltic Sea: A model study. J. Geophys. Res. 115, 1-14.

ICES (2018). Oceanography data portal. http://www.ices.dk/marine-data/dataportals/Pages/ocean.aspx (04.11.18)

Jansson, I.-M., Mertens, K. N., Head, M. J., de Vernal, A., Londeix, L., Marret, F., Matthiessen, J., Sangiorgi, F. (2014) Statistically assessing the correlation between salinity and morphology in cysts produced by the dinoflagellate Protoceratium reticulatum from surface sediments of the North Atlantic Ocean, Mediterranean-Marmara-Black Sea region, and Baltic-KattegatSkagerrak estuarine system. Palaeogeogr. Palaeoclimatol. Palaeoecol. 399, 202-213.

Johansson, J. (2017) Total and regional runoff to the Baltic Sea. HELCOM Baltic Sea Environment Fact Sheets. http://www.helcom.fi/baltic-sea-trends/environment-factsheets/hydrography/total-and-regional-runoff-to-the-baltic-sea (04.11.18)

Kabel, K., Moros, M., Porsche, C., Neumann, T., Adolphi, F., Andersen, T. J., Siegel, H., Gerth, 
M., Leipe, T., Jansen, E., Sinninghe Damsté J. S. (2012) Impact of climate change on the Baltic Sea ecosystem over the past 1,000 years. Nat. Clim. Chang. 2, 871-874.

Klais, R., Tamminen, T., Kremp, A., Spilling, K., Olli, K. (2011) Decadal-scale changes of dinoflagellates and diatoms in the anomalous Baltic Sea spring bloom. PLoS One 6, e21567.

Kotilainen, A. T., Arppe, L., Dobosz, S., Jansen, E., Kabel, K., Karhu, J., Kotilainen, M. M., Kuijpers, A., Lougheed, H. E., Meier, M., Moros, M., Neumann, T., Porsche, C., Poulsen, N., Rasmussen, P., Ribeiro, S., Risebrobakken, B., Ryabchuk, D., Schimanke, S., Snowball, I., Spiridonov, M., Virtasalo, J. J., Weckström, K., Witkowski, A., Zhamoida, V. (2014) Echoes from the past: A healthy Baltic Sea requires more effort. Ambio 43, 60-68.

Kotthoff, U., Groeneveld, J., Ash, J. A., Fanget, A.-S., Krupinski, N. Q., Peyron, O., Stepanova, A., Warnock, J., van Helmond, N. A. G. M., Passey, B., H., Clausen, O. R., Bennike, O., Andrén, E., Granoszewski, W., Andrén, T., Filipsson, H. L., Seidenkrantz, M.-S., Slomp, C. P., Bauersachs, T. (2017) Reconstructing Holocene temperature and salinity variations in the western Baltic Sea region: A multi-proxy comparison from the Little Belt (IODP Expedition 347 , Site M0059). Biogeosciences 14, 5607-5632.

Kremp, A. (2000a) Distribution, dynamics and in situ seeding potential of Scrippsiella hangoei (Dinophyceae) cyst populations from the Baltic Sea. J. Plankton Res.22, 2155-2169.

Kremp, A. (2000b) Morphology and germination pattern of the resting cyst of Peridiniella catenata (Dinophyceae) from the Baltic Sea. Phycologia 39, 183-186.

Kremp, A., Hinners, J., Klais, R., Leppänen, A., Kallio, A. (2018) Patterns of vertical cyst distribution and survival in 100-year-old sediment archives of three spring dinoflagellate species from the Northern Baltic Sea. Eur. J. Phycol. 53, 1-11.

Kremp, A., Rengefors, K., Montresor, M. (2009) Species specific encystment patterns in three Baltic cold-water dinoflagellates: The role of multiple cues in resting cyst formation. Limnol. Oceanogr. 54, 1125-1138.

Kronsell, J., Andersson, P. (2013) Total and regional runoff to the Baltic Sea. HELCOM Baltic Sea Environment Fact Sheets.

Lass, H.-U., Matthäus, W. (2008) General Oceanography of the Baltic Sea. In, State and Evolution of the Baltic Sea, 1952-2005. John Wiley \& Sons, Inc., pp. 5-43.

Leppäranta, M., Myrberg, K. (2009) Physical Oceanography of the Baltic Sea Springer-Praxis, Berlin.

Lepš, J., Šmilauer, P. (2003) Multivariate Analysis of Ecological Data using CANOCO Cambridge University Press, New York.

Lips, I., Rünk, N., Kikas, V., Meerits, A., Lips, U. (2014) High-resolution dynamics of the spring bloom in the Gulf of Finland of the Baltic Sea. J. Mar. Syst.129, 135-149

Margalef, R., Estrada, M., Blasco, D. (1979) Functional morphology of organisms involved in red tides, as adapted to decaying turbulence. In, Taylor, D., Seliger, H. (eds), Toxic Dinoflagellate Blooms. Elsevier, New York, pp. 89-94.

Matthäus, W. (2006) The history of investigation of salt water inflows into the Baltic Sea from the early beginning to recent results. Mar. Sci. Rep. 65, 1-73. https://www.iowarnemuende.de/tl_files/forschung/meereswissenschaftliche-berichte/mebe65_2006.pdf (17.11.18)

Meier, H. E. M., Eilola, K., Gustafsson, B. G., Kuznetsov, I., Neumann, T., Savchuk, O. P. (2012) Uncertainty assessment of projected ecological quality indicators in future climate. Oceanography, no. 112. http://www.smhi.se/polopoly_fs/1.20612!Oceanografi_112.pdf (04.11.18)

Mertens, K. N., Bradley, L. R., Takano, Y., Mudie, P. J., Marret, F., Aksu, A. E., Hiscott, R. N., Verleye, T. J., Mousing, E. A., Smyrnova, L. L., Bagheri, S., Mansor, M., Pospelova, V., 
Matsuoka, K. (2012a) Quantitative estimation of Holocene surface salinity variation in the Black Sea using dinoflagellate cyst process length. Quat. Sci. Rev. 39, 45-59.

Mertens, K. N., Bringué, M., Van Nieuwenhove, N., Takano, Y., Pospelova, V., Rochon, A., De Vernal, A., Radio, T., Dale, B., Patterson, T., R., Weckström, K., Andrén, E., Louwye, S., Matsuoka, K. (2012b) Process length variation of the cyst of the dinoflagellate Protoceratium reticulatum in the North Pacific and Baltic-Skagerrak region: calibration as an annual density proxy and first evidence of pseudo-cryptic speciation. J. Quat. Sci. 27, 734-744.

Mertens, K. N., Dale, B., Ellegaard, M., Jansson, I. M., Godhe, A., Kremp, A., Louwye, S. (2011) Process length variation in cysts of the dinoflagellate Protoceratium reticulatum, from surface sediments of the Baltic-Kattegat-Skagerrak estuarine system: A regional salinity proxy. Boreas 40, 242-255.

Mertens, K. N., Verhoeven, K., Verleye, T., Louwye, S., Amorim, A., Deaf, A.S., Harding, I. C., De Schepper, S., González, C., Kodrans-Nsiah, M., De Vernal, A., Henry, M., Dybkjaer, K., Poulsen, N. E., Feist-Burkhardt, S., Chitolie, J., Heilmann-Causen, C., Londeix, L., Turon, J.L., Marret, F., Matthiessen, J., Mccarthy, F. M. G., Prasad, V., Pospelova, V., Kyffin Hughes, J. E., Riding, J. B., Rochon, A., Sangiorgi, F., Welters, N., Sinclair, N., Thun, C., Soliman, A., Van Nieuwenhove, N., Vink, A., Young, M. (2009) Determining the absolute abundance of dinoflagellate cysts in recent marine sediments : The Lycopodium marker-grain method put to the test. Rev. Palaeobot. Palynol. 157, 238-252.National Weather Service (2017) Monthly NAO index data. http://www.cpc.ncep.noaa.gov/products/precip/CWlink/pna/norm.nao.monthly.b5001.current.a scii.table (04.11.18)

Ning, W., Andersson, P. S., Ghosh, A., Khan, M., Filipsson, H. L. (2017) Quantitative salinity reconstructions of the Baltic Sea during the mid-Holocene. Boreas 46, 100-110.

Ojaveer, H., Jaanus, A., Mackenzie, B. R., Martin, G., Olenin, S., Telesh, I., Zettler, M. L., Zaiko, A. (2010) Status of Biodiversity in the Baltic Sea. PLoS One 5, e12467.

Oksanen, J., Blanchet, F. G., Friendly, M., Kindt, R., Legendre, P., McGlinn, D., Minchin, P. R., O'Hara, R. B., Simpson, G. L., Solymos, P., Stevens, M. H. H., Szoecs, E., Wagner, H. (2018) vegan: Community Ecology Package. $\mathrm{R}$ package version 2.5-2.

Olli, K., Trunov, K. (2010) Abundance and distribution of vernal bloom dinoflagellate cysts in the Gulf of Finland and Gulf of Riga (the Baltic Sea). Deep Sea Res. Part II57, 235-242.

Price, A. M., Baustian, M. M., Turner, R. E., Rabalais, N. N, Chmura, G. L. (2018) Dinoflagellate Cysts Track Eutrophication in the Northern Gulf of Mexico. Estuaries and Coasts 41 (5) 1322-1336. Price, A. M., Coffin, M. R. S., Pospelova, V., Latimer, J. S., Chmura, G.L. (2017) Effect of nutrient pollution on dinoflagellate cyst assemblages across estuaries of the NW Atlantic. 121, 339351.

Price, A. M., Pospelova, V. (2011) High-resolution sediment trap study of organic-walled dinoflagellate cyst production and biogenic silica flux in Saanich Inlet (BC, Canada). Mar. Micropaleontol. 80, 18-43.

Ribeiro, S., Amorim, A., Abrantes, F., and Ellegaard, M. (2016) Environmental change in the Western Iberia Upwelling Ecosystem since the preindustrial period revealed by dinoflagellate cyst records. The Holocene 26, 874-889.

Schlieper, C. (1971) Physiology of brackish water. In, Remane, A. and Schlipper ,C. (eds), Biology of Brackish Water. E. Schweizerbartsche Verlagsbuchhandlung (Nägle u. Obersmiller), Ljubljana, pp. 211-350.

Schlitzer, R. (2017) Ocean Data View, version 4.7.4. https://odv.awi.de/ (04.11.18)

Sildever, S., Andersen, T. J., Ribeiro, S., and Ellegaard, M. (2015) Influence of surface salinity gradient on dinoflagellate cyst community structure, abundance and morphology in the Baltic 
Sea, Kattegat and Skagerrak. Estuar. Coast. Shelf Sci. 155, 1-7.

Sildever, S., Kremp, A., Enke, A., Buschmann, F., Maljutenko, I., and Lips, I. (2017) Spring-bloom dinoflagellate cyst dynamics in three Eastern sub-basins of the Baltic Sea. Cont. Shelf Res. 137, 46-55.

Sorrel, P., Popescu, S. M., Head, M. J., Suc, J. P., Klotz, S., Oberhänsli, H. (2006) Hydrographic development of the Aral Sea during the last 2000 years based on a quantitative analysis of dinoflagellate cysts. Palaeogeogr. Palaeoclimatol. Palaeoecol. 234, 304-327.

Spilling, K., Olli, K., Lehtoranta, J., Kremp, A., Tedesco, L., Tamelander, T., Klais, R., Peltonen, H., Tamminen, T. 2018. Shifting Diatom-Dinoflagellate Dominance During Spring Bloom in the Baltic Sea and its Potential Effects on Biogeochemical Cycling. Front. Mar. Sci. 5, 327.

Stigebrandt, A. (2001) Physical Oceanography of the Baltic Sea. In, Wulff, F. V., Rahm, L. A., Larsson, P. (eds), A Systems Analysis of the Baltic Sea. Springer-Verlag, Berlin, pp. 19-68.

Stockmarr, J. (1971) Tablets with spores used in absolute pollen analysis. Pollen et Spores 13, 615621.

von Storch, H., Omstedt, A., Pawlak, J., Reckermann, M. (2015) Introduction and Summary. In, The BACC II Author Team (eds.), Second Assessment of Climate Change for the Baltic Sea Basin. Springer International Publishing, Cham, pp. 1-22.

Sundström, A. M., Kremp, A., Daugbjerg, N., Moestrup, Ø., Ellegaard, M., Hansen, R., Hajdu, S. (2009) Gymnodinium corollarium so. nov. (Dinophyceae) - a new cold water dinoflagellate responsible for cyst sedimentation events in the Baltic Sea. J. Phycol. 45, 938-952.

Tamminen, T., Andersen, T. (2007) Seasonal phytoplankton nutrient limitation patterns as revealed by bioassays over Baltic Sea gradients of salinity and eutrophication. Mar. Ecol. Prog. Ser. 340, 121-138.

R Core Team (2018). R: A language and environment for statistical computing. R Foundation for Statistical Computing, Vienna, Austria. http://www.R-project.org/ (05.11.18)

Verleye, T. J., Mertens, K. N., Louwye, S., Arz, H. W. (2009) Holocene Salinity Changes in the Southwestern Black Sea: A Reconstruction Based on Dinoflagellate Cysts. Palynology 33, 77100.

Wall, D., Dale., B. 1973. Paleosalinity relationships of dinoflagellates in the Quaternary of the Black Sea- a summary. Geosci. Man, 7, 95-102.

Warden, L., van der Meer, M. T. J., Moros, M., Sinninghe Damsté, J. S. (2016) Sedimentary alkenone distributions reflect salinity changes in the Baltic Sea over the Holocene. Org. Geochem. 102, 30-44.

Wasmund, N., Uhlig, S. (2003) Phytoplankton trends in the Baltic Sea. ICES J. Mar. Sci. 60, 177186.

Weckström, K., Lewis, J. P., Andrén, E., Ellegaard, M., Rasmussen, P., Telford, R. (2017) Palaeoenvironmental History of the Baltic Sea: One of the Largest Brackish-Water Ecosystems in the World. In: Weckström K., Saunders K., Gell P., Skilbeck C. (eds) Applications of Paleoenvironmental Techniques in Estuarine Studies. Developments in Paleoenvironmental Research, vol 20. Springer Netherlands, Dordrecht, pp. 615-662.Widerlund, A., Andersson, P. S. (2011) Late Holocene freshening of the Baltic Sea derived from high-resolution strontium isotope analyses of mollusk shells. Geology 39, 187-190.

Willumsen, P. S., Filipsson, H. L., Reinholdsson, M., Lenz, C. (2013) Surface salinity and nutrient variations during the Littorina Stage in the Fårö Deep, Baltic Sea. Boreas 42, 210-223.

$\mathrm{Yu}$, S. Y. and Berglund, B. E. (2007) A dinoflagellate cyst record of Holocene climate and hydrological changes along the southeastern Swedish Baltic coast. Quat. Res. 67, 215-224.

Zonneveld, K.A.F., Bockelmann, F., Holzwarth, U., 2007. Selective preservation of organic-walled dinoflagellate cysts as a tool to quantify past net primary production and bottom water oxygen 
concentrations. Mar. Geol. 237, 109-126. 


\begin{tabular}{|c|c|c|c|c|c|c|c|c|c|}
\hline $\begin{array}{l}\text { Microfossil } \\
\text { data } \\
\text { coverage }\end{array}$ & $\begin{array}{l}\text { Species/ } \\
\text { groups } \\
\text { included }\end{array}$ & $\begin{array}{l}\text { DCA } \\
\text { length }\end{array}$ & $\begin{array}{l}\text { Further } \\
\text { test }\end{array}$ & $\begin{array}{l}\text { Environmental } \\
\text { parameters } \\
\text { tested }\end{array}$ & Season & $\begin{array}{l}\text { Global } \\
\text { test } P \text { - } \\
\text { value }\end{array}$ & $\begin{array}{l}\text { Sign. } \\
\text { axis ( } P \text { - } \\
\text { value) }\end{array}$ & $\begin{array}{l}\text { Sign. env. } \\
\text { param. } \\
\text { (terms) } \\
(P \text {-value) }\end{array}$ & $\begin{array}{l}\text { Sign. env. } \\
\text { param. } \\
\text { (margin) ( } P \text { - } \\
\text { value) }\end{array}$ \\
\hline 1880-2009 & All & 1.58 & PCA & & & & & & \\
\hline \multirow[t]{3}{*}{ 1983-2009 } & All & 1.41 & RDA & $\begin{array}{l}\mathrm{SSS}, \mathrm{SST}, \mathrm{NAO} \\
\mathrm{P}, \mathrm{NO}_{3}\end{array}$ & Dec.-Feb. & 0.23 & & & \\
\hline & Spring & 0.83 & & $\mathrm{SSS}, \mathrm{SST}, \mathrm{NO}_{3}$ & & 0.39 & & & \\
\hline & Summer & 1.01 & & $\begin{array}{l}\text { SSS, SST, NAO, } \\
\mathrm{P}, \mathrm{NO}_{3}\end{array}$ & & 0.44 & & & \\
\hline \multirow[t]{12}{*}{$1975-2009$} & All & 1.53 & RDA & $\begin{array}{l}\text { SSS, SST, NAO, } \\
\mathrm{P}_{1} \mathrm{NO}_{3}\end{array}$ & March-May & 0.04 & 1. $(0.04)$ & SSS (0.03) & SSS (0.04) \\
\hline & & & & & June-August & 0.07 & & & \\
\hline & & & & & July-Sept. & 0.11 & & & \\
\hline & & & & & Annual & 0.17 & & & \\
\hline & Spring & 1.01 & RDA & $\mathrm{SSS}, \mathrm{SST}, \mathrm{NO}_{3}$ & March-May & 0.02 & 1. $(0.01)$ & $\mathrm{NO}_{3}(0.02)$ & $\begin{array}{l}\left.\text { SSS }(\boldsymbol{\beta}, .01)_{2}\right) \\
\mathrm{NO}_{3}(\mathbf{0 . 0 1})\end{array}$ \\
\hline & & & & & June-August & 0.43 & & & \\
\hline & & & & & July-Sept. & 0.35 & & & \\
\hline & & & & & Annual & 0.31 & & & \\
\hline & Summer & 0.99 & RDA & $\begin{array}{l}\text { SSS, SST, NAO, } \\
\mathrm{P}, \mathrm{NO}_{3}\end{array}$ & March-May & 0.03 & 1. $(0.04)$ & SSS (0.02) & SSS (0.02) \\
\hline & & & & & June-August & 0.03 & 1. $(0.02)$ & $\begin{array}{l}\text { SSS }(0.01) / \\
\text { NAO (0.03) }\end{array}$ & \\
\hline & & & & & July-Sept. & 0.11 & & & \\
\hline & & & & & Annual & 0.11 & & & \\
\hline
\end{tabular}


Highlights

- Dinoflagellate cyst assemblage analysis from $19^{\text {th }}$ century to present;

- Statistical analysis on the influence of environmental parameters to microfossils;

- Average summer sea surface salinity reconstructions based on cyst morphology;

- Most abundant species were Protoceratium reticulatum and Biecheleria baltica;

- Spring SSS, $\mathrm{NO}_{3}$, summer SSS, NAO best explained variability in microfossil abundances;

- Cyst assemblages and morphology reflected major environmental changes 